\title{
Induction of phenotypically determined resistance of Neisseria gonorrhoeae to human serum by sera from patients with gonorrhoea
}

\author{
P M V MARTIN, P V PATEL, N J PARSONS, AND H SMITH \\ From the Department of Microbiology, University of Birmingham, Birmingham
}

SUMMARY Some human sera contain factors which induce in gonococci a resistance to killing by $\stackrel{\infty}{=}$ fresh human sera. Individuals with serum containing these factors might possibly be more prone to $\mathrm{c}_{\infty}$ gonorrhoea. A survey of the sera of 50 female and 50 male patients with gonorrhoea for or resistance-inducing capacity showed, however, that the proportions of positive sera $\left(24 \%\right.$ for $\omega_{0}$ women, $28 \%$ for men) were not significantly different from those (16\% for women, $24 \%$ for men) from an equal number of controls. Examination of the results, however, in relation to the type of gonococcal infection showed that: (a) the sera of 15 female patients with complicated (salpingitis) or successive infection or both did not induce resistance (statistically significant); (b) a greater proportion (34\%) of sera from female patients with single gonococcal infections induced higher gonococcal resistance than for control sera $(16 \%)$ (at the borderline of statistical significance); and (c) a greater proportion $(\mathbf{3 8 \%})$ of sera from the few male patients with successive infections induced higher resistance than for control sera (24\%) (not statistically significant).

\section{Introduction}

The resistance of Neisseria gonorrhoeae to killing by normal human serum, considered to be an important factor in pathogenesis, ${ }^{1}$ is of two different types. The first type is retained after several subcultures of the organisms in vitro and concerns most strains isolated from disseminated gonococcal infection. ${ }^{2}$ The second type concerns mainly strains isolated from acute urogenital infections in men or women and is phenotypically determined; it is exhibited by gonococci grown in vivo (that is, from urethral exudate) but is lost after subculture in normal laboratory media. ${ }^{3}$ Recently, the latter type of resistance has been induced in a synthetic medium in vitro by guinea pig sera ${ }^{4}$ and by a proportion (about $25 \%$ ) of sera taken from healthy human donors. ${ }^{5}$ With a positive serum, conversion of a serumsensitive strain to serum resistance occurred in three hours at $37^{\circ} \mathrm{C}$ and better at a slightly acid $\mathrm{pH} .{ }^{5}$ The inducing capacity of serum was increased by freezing and thawing and was due to factors of both high and low molecular weights. ${ }^{5}$

Address for reprints: Professor $\mathbf{H}$ Smith, Department of Microbiology, South-west Campus, University of Birmingham, PO Box 363, Birmingham B15 2TT

Accepted for publication 31 March 1982
The possible importance of the resistance-inducing factor in the pathogenesis of gonorrhoea was further emphasised by the recent finding that vaginocervical secretions and seminal plasmas have a resistanceinducing activity as shown by some human sera. ${ }^{6}$ Individuals who form the resistance-inducing factors might, therefore, possibly be more prone to gonorrhoea than those in whom the factors could not be detected. Hence, the resistance capacities of sera from 100 patients ( 50 men and 50 women) were compared with those of sera from 100 controls.

\section{Materials and methods}

SERA

The sera of 100 patients ( 50 women and 50 men) attending the venereal disease clinic of the $N$ Birmingham General Hospital were examined in 1981 by the the courtesy of Dr J F Clay. In all patients gonorrhoea was diagnosed by microscopy of stained $\mathrm{\omega}$ smears and culture for $N$ gonorrhoeae. Some patients $\underset{2}{\sigma}$ had a previous history of gonorrhoea and others had 0 complications of infection, for example, salpingitis. Blood $(10 \mathrm{ml})$ was collected by venous puncture before treatment and clotted at room temperature for 1-2 hours. After standing at $4^{\circ} \mathrm{C}$ for 48 hours the sera were separated and heat-inactivated $\left(\right.$ at $56^{\circ} \mathrm{C}$ for 40 minutes). 
As controls, blood samples from 100 healthy donors ( 50 women and 50 men of similar age range as the patients) of the National Blood Transfusion Service, Birmingham, were similarly heated and in parallel. All sera from patients and controls were screened for hepatitis agents before use.

The sera were tested for resistance-inducing activity before and after one, three, and sometimes four freezings (at $-20^{\circ} \mathrm{C}$ ) and thawings $\left(\right.$ at $\left.37^{\circ} \mathrm{C}\right) .^{5}$

\section{SERUM-SENSITIVE NEISSERIA GONORRHOEAE}

This was strain BS4 (agar) derived, stored, and cultured as described. ${ }^{7}$

Viable counts and defined medium (DM) were as described. ${ }^{89}$

\section{GENERATION OF RESISTANT ORGANISMS.}

This was performed as described. ${ }^{9}$ The medium $(100$ $\mu l)$ consisted of a $1 / 1$ mixture of DM and serum at a final $\mathrm{pH}$ of $6 \cdot 4-6 \cdot 6$. Serum-sensitive gonococci $\left(5 \times 10^{4} / \mathrm{ml}\right.$ in $10 \mu \mathrm{l}$ of DM) were added in the wells of microtitre plates (Flow laboratories, Irvine, Scotland) and incubated for three hours at $37^{\circ} \mathrm{C}$. Estimates of growth were made by plating out duplicates $(10 \mu \mathrm{l})$ of the mixture before and after incubation.

Serum resistance was measured as described. ${ }^{9}$ The number of colony forming units (cfu) recovered after incubation of the above suspension of organisms $\left(0.5-1.0 \times 10^{4}\right.$ organisms) for 40 minutes at $37^{\circ} \mathrm{C}$ with fresh human serum (FHS) was given as a percentage of the number of units obtained when heat-inactivated serum $\left(56^{\circ} \mathrm{C}\right.$ for 60 minutes) was used.

\section{Results}

The sera were tested before and after freezing and thawing and the results confirmed the increase in resistance-inducing activity which has been noted before. ${ }^{5}$ Thus, the mean percentages of strain BS4 (agar) rendered serum-resistant in the standard procedure by sera that were examined before freezing and thawing and after one and three (or four) freezings and thawings were: 20,23 , and 22 for the 50 female patients respectively; 7,18 , and 15 for the 50 female controls respectively; 17, 20, and 32 for the 50 male patients respectively; and 13,22 , and 36 for the 50 male controls respectively. The figures in table I were derived from one value for percentage conversion by each serum; this was the highest percentage recorded, usually after the third (or fourth) freeze-thawing but sometimes after the first.

Table I shows that the proportion of sera inducing serum resistance to more than $50 \%$ of the gonococci was $24 \%$ for female patients compared with $16 \%$ for
TABLE I Ability of sera from patients with gonorrhoea and controls to induce serum resistance in Neisseria gonorrhoeae

\begin{tabular}{lccccc}
\hline & \multicolumn{5}{c}{$\begin{array}{l}\text { No inducing resistance of strain } \\
\text { BS4 (agar) to FHS at following } \\
\text { percentages: }\end{array}$} \\
\cline { 2 - 6 } Origin of & Total & & \\
\cline { 2 - 6 } sera & No & $0-20$ & $21-50$ & $51-80$ & $>80$ \\
\hline Female patients & 50 & 33 & 5 & 2 & 10 \\
$\quad$ With previous history* & 11 & 9 & 2 & 0 & 0 \\
$\quad$ With complicationst & 7 & 7 & 0 & 0 & 0 \\
Female controls & 50 & 38 & 4 & 2 & 6 \\
Male patients & 50 & 25 & 11 & 4 & 10 \\
$\quad$ With previous history* & 13 & 6 & 2 & 2 & 3 \\
Male controls & 50 & 21 & 17 & 4 & 8 \\
\hline
\end{tabular}

*Of gonorrhoea

+For example, salpingitis

the controls and $28 \%$ for the male patients compared with $25 \%$ for the controls. The differences were not significant but a more detailed examination showed some interesting trends.

None of the seven female patients with complicated infections had sera which induced resistance and only two of 11 female patients with a previous history of infection had active sera and then at a very low level. There was no significant difference between the results of the sera of either of these two subdivisions of the female patients and those of the sera of the remaining patients with gonorrhoea. If the results of the sera from female patients with either complicated or repeat infections are combined, however, and viewed with respect to their ability to induce serum resistance to more than $50 \%$ of the standard inoculum (table II; three patients had both repeat infections and salpingitis), a significant difference was present between them (group 2, table II) and those of the sera of female patients with a first episode of uncomplicated gonorrhoea (group 1) $\left(\chi^{2}\right.$ test with Yates's correction, $\left.\mathrm{P}<0 \cdot 05\right)$. Furthermore, when the proportion of sera of group 1 inducing serum resistance to more than $50 \%$ of the gonococci ( $34 \%$ of a total of 35 sera, table II) were

TABLE II Ability of sera from female patients without or with complicated or repeat gonococcal infection or both to induce resistance in Neisseria gonorrhoeae compared with healthy controls

\begin{tabular}{lllc}
\hline & $\begin{array}{l}\text { No inducing resistance of } \\
\text { strain BS4 tagar) to FHS at } \\
\text { following percemtages: }\end{array}$ \\
$\begin{array}{l}\text { Total } \\
\text { Nerigin of }\end{array}$ & $0-50$ & $5 l-l 00$ \\
\hline $\begin{array}{l}\text { Nemale controls } \\
\text { Female patients }\end{array}$ & 50 & 42 & 8 \\
Group 1* & 35 & 23 & 12 \\
Group 2t & 15 & 15 & 0 \\
\hline
\end{tabular}

*With first uncomplicated episode of gonorrhoca

+With either complicated (salpingitis) or repeat gonococial infection 
compared with the corresponding proportion of control sera ( $16 \%$ of a total of 50$)$ the proportion for the sera from the patients with gonorrhoea was on the borderline of being significantly greater $\left(\chi^{2}=3.78, \mathrm{P}<0.052 ; \chi_{1}^{2}=3.84, \mathrm{P}<0.05\right)$ than that for the control sera. For the sera from the male patients, the proportion of sera inducing serum resistance to more than $50 \%$ of the gonococci was $24 \%$ (of a total of 37) for patients with single infections and $38 \%$ (of a total of 13) for the sera of patients with repeat infections. Although this figure was higher than that for the control sera (24\% of 50 sera) it was not statistically significant because of the small numbers involved.

The blood grouping of 67 female patients and controls were known but no correlations could be drawn between induction of serum resistance and $A$, $\mathrm{B}, \mathrm{O}$, or rhesus blood grouping.

\section{Discussion}

At first sight the results of this survey were disappointing in terms of a possible relation between the presence of the inducing factor in serum and ease or severity of the gonococcal infection. There was no significant difference between the overall results of the sera of female patients, female controls, male patients, and male controls. However, some interesting trends came from a closer examination in relation to the type of gonococcal infection suffered by the patients.

First, the sera of the few female patients with complicated gonococcal infections (notably salpingitis) and of the small number with a previous history of gonococcal infection showed a conspicuous lack of resistance-inducing activity. When the results of the sera from patients with complicated or successive gonococcal infection or both were combined and compared with those of the sera of patients with uncomplicated infection (Table II), a significant difference $(\mathrm{P}<0.05)$ emerged, indicating an inverse relationship between severity and repeated infection and the presence of the resistance-inducing factors. This inverse relationship may indicate that the absence of the gonococcal surface determinant of phenotypic serum resistance in these patients allows other determinants of pathogenicity, such as those causing inhibition of ingestion or killing of gonococci by phagocytes, to operate more freely leading to increased invasion of the host.

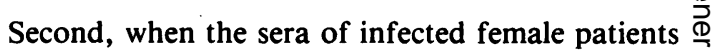
with neither uncomplicated nor repetitive infection were viewed alone and compared with the control sera, the proportion of sera inducing high gonococcal $\vec{F}$ resistance was greater for the sera of the infected patients. Here then was a suggestion of a relation between the presence of the inducing factor and ease of infection. Another along the same lines but more tenuous because of the small numbers of samples involved was the fact that the sera of male patients 0 with repeated infection contained a higher $\vec{\circ}$ proportion of samples inducing high gonococcal $\rightarrow$ resistance than the sera of controls.

These interesting trends warrant further comparisons with larger numbers of sera from female and male patients whose type of gonococcal infections are known.

The authors wish to thank $\mathrm{Mr}$ Loebb and the technical staff of the National Blood Transfusion Service, Birmingham, for their helpful assistance in screening sera for hepatitis agents.

\section{References}

1. Brooks GF, Gotschlich EC, Holmes KK, Sawyer WD, Young FE. Immunobiology of Neisseria gonorrhoeae. Washington DC: American Society for Microbiology, 1978.

2. Schoolnik GK, Buchanan TM, Holmes KK. Gonococci causing disseminated gonococcal infection are more resistant to the bactericidal action of normal human sera. J. Clin Invest 1976;58:1163-73.

3. Ward ME, Watt PJ, Glynn AA. Gonococci in urethral exudate possess a virulence factor lost on subculture. Nature 1970;227:382-4.

4. Veale DR, Penn CW, Parsons NJ, Smith H. Preliminary studies of a factor in guinea pig serum which induces serum resistance in Neisseria gonorrhoeae. Soc Gen Microbiol Quarterly 1980;7:188.

5. Martin PMV, Patel PV, Parsons NJ, Smith H. Induction of phenotypically determined resistance of Neisseria gonorrhoeae to human serum by factors in human serum. J Gen Microbio 1981;127:213-7.

6. Martin PMV, Patel PV, Parsons NJ, Smith $\mathbf{H}$. Induction in gonococci of phenotypic resistance to killing by human serum by human genital secretions. Br J Vener Dis 1982; in press.

7. Penn CW Veale DR, Smith $H$. Selection from gonococci grown in vitro of a colony type with some virulence properties of organisms adapted in vivo. J Gen Microbiol 1977; 100:147-58.

8. Veale DR, Smith H, Witt KA, Marshall RB. Differential ability of colonial types of Neisseria gonorrhoeae to produce infection $N$ and an inflammatory response in subcutaneous perforated $\sigma$ plastic chambers in guinea pigs and rabbits. J Med Microbiol N 1975;8:325-35.

9. Veale DR, Penn CW, Smith $\mathbf{H}$. Factors affecting the induction of phenotypically determined serum resistance of Neisseria gonorrhoeae grown in media containing serum or its diffusible components. J Gen Microbiol 1981;122:235-45. 